\title{
O Ensaio em LuKács: Estilo Tardio e a Forma da JUVENTUDE
}

\author{
Cesar Kiraly ${ }^{1}$
}

Resumo: No presente ensaio, procuro estabelecer afinidade de leitura entre a tradição cética e a dialética, por intermédio do conceito de crítica.

Palavras-Chave: Lukács. Ceticismo. Dialética.

\section{I}

Se tudo for muito rápido, aceitarmos a diferença entre o ceticismo e a dialética seria comum e imperioso, mais ainda, haveria inultrapassável abismo entre essas duas formas de pensar. As relaçóes seriam instrumentais, quase diplomáticas, o cético teria apenas tratamento, a oferecer ao adoecido dialético, e esse tấo somente uma relação instrumental com aquele, como passo anterior, ou renovador, da sua própria trajetória. Os rebatimentos históricos seriam, grosso modo, a recepção mais intensa do ceticismo pela filosofia analítica, e sua suposta concisão vocabular, e a dialética pela filosofia continental, e sua paciência com o conceito, aprofundando a distância. Mas parece que não é nada disso. Se atentássemos um pouco mais, não demoraríamos por admitir a pouca credibilidade de uma separação verdadeira. No mais das vezes, trata-se de uma forma de escolher, por espelhamento, como queremos nos expressar e o tipo de leitura que apreciamos fazer, ou de antecipar os livros de filosofia que detestamos, sem ler. No ensaio, como gênero da escrita filosófica, a conversa é completamente outra. Ele é uma terra pertencente a céticos e dialéticos e que precisa ser compartilhada. A hipótese de dois estados aqui parece absurda de todo. Trata-se de um lugar que precisa ser compartilhado de sorte a não sabermos mais quem é quem. $\mathrm{O}$ remetimento às origens precisaria ser feito de modo delicado, para não se tornar um ardil para impedir tal forma misturada.

\footnotetext{
${ }^{1}$ Professor de Estética e Teoria Política no Departamento de Ciência Política da UFF. Autor, dentre outros, do livro Ceticismo e Política. E-mail: ckiraly@id.uff.br

http://dx.doi.org/10.1590/S0101-31732017000100004
} 
Parece que essa habitação inaugura formas inesperadas de descrever, de continuar uma voz antecedente que se interrompe antes do fim. $\mathrm{O}$ ensaio, pela capacidade de inovaçáo formal, seduz, inadvertidamente, a dialética a se dissolver em ceticismo, alterando-o geneticamente. O ensaísta é aquele que atende ao chamado do artista e do cientista dissolvidos em novo amálgama.

\section{II}

Existe um largo acordo moral acerca da necessidade do vínculo do pensamento com o exercício da crítica. Um pouco independente da posição conceitual do pensamento, sabemos que será melhor se for crítico. Assim, a despeito das discordâncias, é a crítica que mantém dutos de conversação entre discursos diferentes, entre tempos distintos. E é a capacidade de um pensamento ser crítico que permite mudar suas características, sem perder a identidade. $\mathrm{Ou}$, em casos mais extremos, é o exercício crítico que torna viável o abandono de um nome para a aquisição de um outro, novo. Nem sempre a crítica aparece por suas razões intrínsecas, por vezes, ela é despertada. Porém, a crise existencial, a experiência negativa, sem um território crítico, torna-se destrutividade ou humor; mas náo necessariamente troca de identidade ou mudança.

Ainda que o pensamento, do ponto de vista moral, seja melhor quando crítico, existe aquele que se afirma na completa aversão a tal ambiente. A crítica não faz falta ao mundo grego. Anselmo, Hegel e Heidegger são geniais - monstruosos, cada um de seu próprio jeito - na proporção em que não são críticos. Mesmo não sendo crítico, um pensador pode ser fundamental para uma tradição crítica. Mesmo sendo pouco crítico, um autor pode fazer da crítica o seu objeto.

Acredito que três sejam as mais importantes tradiçôes críticas: (i) a cética, (ii) a kantiana e (iii) a marxista. A crítica cética é a mais tradicional das três, pois se inicia com Montaigne, La Boétie e Pierre Bayle, e, apesar de sua difusa circunscrição, tem como elemento a busca de composição com a reticência dos céticos gregos e helênicos com o tema da essência, agregando figuras enigmáticas, como Pirro, Enesidemo e Carnéades, e sistematizadores rigorosos, como Sexto Empírico. A crítica cética flutua sobre essa herança e se adensa por causa da volta do parafuso, noutras palavras, na redescoberta das escrituras céticas do século XVI; nela é que a vocação da ataraxia se transfigura em vínculo filosófico de perscrutação e imersão na diaphonia. A 
crítica cética, por si só, é a mais tradicional das críticas, mas o seu cancioneiro se dá, dentre outras razóes, no conforto que possui com a tradição antiga que abriga como sua, tradição que a inventa e que é incorporada de um modo que só tem existência na deglutição; nesse sentido, a sua falta de limites bem postos é a sua maior virtude. A virada moderna do ceticismo altera o sentido da epoché. O ceticismo crítico é a continuação, buscada, do ceticismo antigo, que é uma coisa outra. Se antes a epoché significara a suspensão do juízo, uma alternativa à isostheneia, no século XVI, seguindo e adquirindo seu sentido completo no XVIII, ela se torna um operador de pictorialidade. A ataraxia do cético moderno tem em comum, com a do filósofo antigo, a aquisição de uma capacidade de vislumbramento, mais especificamente, da composição da experiência.

A crítica kantiana surge do ambiente cético; não é o caso de inflacionar a influência de Hume sobre Kant, mas de admitir que a agenda crítica ultrapassa em muito o kantismo, antes mesmo que ele tenha começado. Num certo sentido, a crítica kantiana pode ser dita menos crítica do que a cética, dentre outras razóes, porque ela se organiza para desenvolver apenas um dos problemas críticos da crítica cética. Kant toma o problema cético do limite, e o investiga numa série de fenômenos distintos. A província cética do limite recebe, de Kant, o nome de transcendental, e o extravasamento do campo da crítica, o nome de transcendência. A liberdade humana atual se torna um problema transcendental, logo, objeto de crítica, e a virtualidade da finalidade humana se torna um problema de transcendência, logo, a cargo da metafísica. Existe uma extensa história das ramificaçóes do kantismo, seja pelo logicismo de Marburgo, seja pelo espiritualismo pré-hermenêutico e axiológico da escola de Baden, todavia, o pertencimento ao reduto do transcendental não empírico é uma característica ampla dessa tradição crítica.

A crítica marxista, a qual será lida sob uma perspectiva cética, muito bem representada pela obra de juventude e tardia de Lukács, surge do ambiente de releitura do transcendental empreendido por Hegel. Não deixa de ser paradoxal o fato do surgimento da crítica marxista sob os auspícios de um dos pensadores mais reativos à crítica, e não crítico, da história da filosofia. Contudo, a incorporação de Hegel por Marx e pelos autores crítico-marxistas, como Lukács, e frankfurtianos, como Adorno e Benjamin, dá-se de modo especial. Antes de tudo, Hegel é um pretexto para uma imanência dialética. Se o transcendental em Kant dá vez à província crítica do limite - da Razão, do entendimento e da imaginação, vendo no desnível das faculdades a origem da 
norma, e de sua finalidade na história para liberdade -, Hegel o pensa como um limite, ilimitado. Essa aparente ilogicidade é por ele resolvida com uma nova lógica, segundo a qual as províncias da consciência e da história não são apartadas, porque constituídas. A sofisticação dos processos de conhecimento, bem descrita por Kant pela Aufklärung com relaçáo à essência do objeto, substitui-se pela evidência da constituição da história, enquanto fenômeno de inteligibilidade da consciência. Assim, aquilo que só poderia ser visto no conflito entre instâncias adquire a natureza de um conflito constitutivo.

Mas, como frisamos, o hegelianismo, puro e simples, não participa da história da crítica, quando muito, marca um capítulo não crítico dos momentos da Aufklärung, pois uma lógica integralista não permite o equívoco ou a sua revisão. A natureza do vício é a negação que constitui a virtude, no tempo. A imanência de Spinoza, para citarmos um outro exemplo, igualmente não admite a crítica. Assim, se Hegel é importante para certa tradição crítica, enquanto elaborador de um artifício de imanência, algum ardil intelectual teve que ser produzido para inocular o raciocínio sobre o limite e a distinçáo no coração do espírito. Para tanto, e Lukács é o inaugurador dessa linhagem, tendo como seguidores Adorno e, de um modo estranho, Benjamin, houve a identificação da história com o transcendental, fazendo com que a dialética deixasse de ser tão somente uma filosofia da natureza para apontar os primeiros traços de uma crítica do constituído na constituição. Nisso foi aberta a possibilidade de uma crítica dialética da sociedade, porque, muito embora desprovida a história de equivocidade, passa a caber ao crítico o esclarecimento acerca da instância possível da verdade no tempo, e negá-la.

Lukács não tira a crítica dialética da cartola, seus fragmentos estavam lá no jovem Marx. Como também seus fragmentos estavam no diálogo do jovem Hegel com o ceticismo. Lukács era especialmente atento à juventude dos seus autores. Ele traz essas filosofias de juventude para o primeiro plano, e nelas planta o seu criticismo acerca dos modos de desintegração do tempo, pelo que se convencionou chamar de modernidade. A crítica dialética aponta a equivocidade atual da verdade presente, uma vez que enuncia desde o virtual histórico. Se Hegel foi capaz de dissolver o transcendental numa imanência-consciência-história, fazendo das penínsulas de faculdades um grande campo devastado e fértil, Lukács revitaliza pela instituição da província crítica, nesse mesmo campo devastado, e o espelha. A crítica de Lukács olha nos olhos do campo devastado e diz: - Campo, estás devastado, mas a devastação é uma das suas naturezas; se houve ordem e perda de 
ordem; haverá ordem épica no campo futuro. ${ }^{2}$

Afastar-nos-emos da crítica kantiana, pelo menos no que for possível, para lermos esse capítulo da crítica marxista de um pouco mais de longe, pelos olhos da crítica cética. A longa tradição, um tanto idosa, lendo essa nova crítica, pelo menos por comparação. A crítica cética olhará sempre por três modos da pictorialidade: (i) a paisagem, (ii) o retrato e (iii) a abstração.

A paisagem é o modo da descrição cética inaugurado por Montaigne, antecipa alguns elementos do retratismo, mas os utiliza em detalhe, pois numa paisagem de crença podem estar contidos vários rostos filosóficos, mas vistos, sobretudo, como comuns, dentre os quais, inclusive, o rosto pressuposto para a contemplação. Em Montaigne, a paisagem pode ser contraditória ou ambivalente, mas nunca deformada, por isso pode pressupor em sua paisagem mais de um rosto que vislumbra. Contudo, uma paisagem pode ter elementos internos de deformaçáo. Mas sempre vistos numa clareza unitária. Ainda que haja vedaçáo à deformidade do landscape, os rostos inseridos podem ser ambivalentes; tais ambivalências podem ter os seus sentidos relacionados. Se o retrato de Bayle é o vislumbramento da crença na ambivalência do rosto filosófico, o retrato na paisagem, na acumulação pictórica de Montaigne, descreve a ambivalência em rostos não filosóficos, em construçôes, em exercícios, em suma, ele descreve a ambivalência do mundo.

O retrato é modalidade da descrição cética inaugurada por Bayle, pela qual, ao se salientar os elementos compositivos de um sistema filosófico, nele se restam mostradas as crenças e, nessas, o rosto humano. $\mathrm{O}$ retrato cético concerne à figurabilidade do rosto humano na enunciaçáo teórica, outrossim, do vislumbramento crença-rosto como indício de sistema-mundo. Não é somente o pigmento da crença que precisa ser tolerado para fazer diagrama, mas algo do seu conteúdo deve ser recebido para fazer rosto. Deve-se tolerar o rosto humano.

Em Hume, a sobreposição, com o abstrato, encontra o seu termo. O retrato permanece, mas perde a sua relevância, que o fazia portador de nomepróprio. Hume faz retratos de Maquiavel e Spinoza, mas eles assumem a presença conceitual de um gênero, como em $O$ Cético ou $O$ Estoico. A descrição de paisagem permanece, no entanto, perde lugar para um princípio abstrato

\footnotetext{
${ }^{2}$ Georg Lukács, A Teoria Do Romance (São Paulo: Ed. 34, 2000). p. 34. "[S]er homem significa ser solitário. E a luz interna não fornece mais do que ao passo seguinte a evidência - ou a aparência - de segurança. De dentro já não irradia mais nenhuma luz sobre o mundo dos acontecimentos e sobre o seu emaranhado alheio à alma."
} 
de pluralidade de planos. O rosto passa a ser retratado enquanto efeito de superfície da natureza humana e a paisagem passa ser descrita como história da representação. A natureza humana é descrita pela sua composição: ideias, impressôes e crenças, e a história também: por crenças, contrastes e fronteiras.

Assim, nessa contraposição de Lukács com o ceticismo, temos duas críticas a rivalizar: a crítica cética, como filosofia política, e a crítica dialética, enquanto filosofia da história. Veremos que a opção pela forma de juventude e pelo estilo de maturidade, como modo de leitura, relativizará a oposição. Entretanto, existe oposição na história das pretensōes políticas entre a filosofia política e a filosofia da história. O percurso da filosofia política é muito mais extenso, e data da ambientação grega. A filosofia da história se inicia no século XVIII. Mas a oposição entre as duas náo se deve apenas a problemas de origem. Deve-se, sobretudo, a razóes de conteúdo conceitual. O filósofo político, quer pela fundação, quer pelo fundamento, descreve um estado de coisas; ele, salvo pela criação de objetos pictóricos, deixa as coisas tal como são e, mais do que perguntar pelas causas, diz o que as causas são e o modo pelo qual vinculam a autoridade. O filósofo da história diz como as coisas se tornaram a ser o que são e aponta, em virtude das causas que perscruta, para onde vão. Ambos possuem ares teológicos, mas o filósofo da história se preocupa com a teogonia, enquanto o político, com a teofania.

Pois bem, se Rousseau, Hegel e Marx são confortavelmente filósofos da história, o mesmo não ocorre com Lukács. Se Locke, Hobbes e Bodin são filósofos políticos, o mesmo náo acontece com a descritividade conceitual de Hume. Salvaguardando as enormes diferenças entre a crítica cética e a crítica dialética, o que nos leva a empreender esse debate é que ambas tradiçóes estão num outro lugar, no qual a descrição abstrata e a invenção deliberada de objetos históricos caminham juntas. Náo só o ceticismo laicizou a crença, como a crítica dialética desvinculou a finalidade de sua estrutura transcendente. Há, nessa medida, um profundo vínculo antiteológico nessas duas tradições críticas.

A leitura conjunta dessas duas formas críticas nos permite ultrapassar o aspecto antiteológico por uma estrutura de pensamento não-teológica. Tal se deve ao fato da observação da criação. De alguma forma, tanto a crítica dialética quanto a crítica cética não podiam se furtar a certa relatividade à teologia, razão pela qual temos a obrigação de esquecer a reatividade, ou têla apenas como contexto, e avançarmos para uma fundação eminentemente estética para a crítica. Contudo, devemos reconhecer o mérito presente na 
laicização da criação; a crítica cética vê a natureza humana criadora de rostos, paisagens e conceitos, e, neste último modo descritivo, no que concerne à crítica dialética, a natureza humana a criar finalidade histórica.

\section{III}

Antes de podermos avançar, precisamos estabelecer um sentido relativamente unificado para a crítica. Estamos menos interessados no radical grego da crítica, e sua acepção jurídica, do que no remetimento a uma ideia prática de julgamento. Nesse sentido, frente a dois objetos indistintos, o crítico - kritikós - é aquele que, de modo experimentado, cria uma ordem. Perceba-se que o crítico só cria uma ordem, porque se dedicou a ver o que a poucos interessa: ele carrega uma espécie de fardo e, no momento em que a distinção, e não a decisão, é necessária, ele conhece por convívio. Numa acepção ampla, pode-se dizer que a crítica se inicia numa jurisprudência, mas não como uma jurisdição.

Koselleck nos lembra do radical de crítica e crise, remetendo-o ao grego $K R I$. E também nos ensina sobre a essencialização da crise, correlacionada à intensa captura médica, principalmente pela noçáo de organismo, mas também nos faz ver que a perda do sentido de um mundo fechado afasta a crítica da crise. Ainda que a crise seja um dos momentos em que se precisa da crítica, apenas a crítica continuada, como um gosto instituído no tempo, é que possibilita exercer a distinção na crise. A crítica não surge em momento de crise, ela apenas é chamada a falar e, se inexistente no momento anterior, não terá nada a dizer (KOSELLECK, 1999, p. 203). Todavia, no que concerne à relaçáo com o poder e com os homens comuns, fora do momento crítico, de crise, os críticos são odiados e suas mortes desejadas ${ }^{3}$, na melhor das hipóteses. ${ }^{4}$

O mais vulgar de crítica surge na Inglaterra do século XVII como criticism, e a partir desse momento o crítico é tido, prevalentemente, um crítico de arte - que, para tanto, é um lógico e um gramático - com profundas preocupaçóes morais e políticas. Nesse sentido, é da natureza da crítica lidar

\footnotetext{
3 “[...] sobre os 'criticks' presunçosos que haviam se tornado igualmente suspeitos aos olhos de príncipes, eruditos, protestantes e católicos; como castigo, a maioria deles teria sido acometida de morte violenta ou maligna." Depois da publicação do Tratado Teológico-Político, existem referências a Spinoza como "um certo crítico judeu." (KOSELLECK, 1999, p. 203).

${ }^{4}$ Deleuze e Foucault viram bem o problema da dissociaçâo entre crítica e crise e a sucessiva captura da crise pelo campo da clínica. O primeiro o faz em alguns ensaios agrupados no sentido geral do volume Crítica e Clínica, enquanto o segundo, numa monografia de título O Nascimento da Clínica.
} 
com a criação de um modo laicizado; a crítica se inicia como crítica de arte, porque a criação é entendida como fenômeno humano que encontra sua maior intensidade na ideia de obra. Por essa razão, o crítico lida com o trabalho filosófico, enquanto imaginação, ou acréscimo de sentido ao mundo. A crítica nasce lidando com a filosofia como quem lida com sistemas de verdade. $\mathrm{O}$ crítico pode ser tomado como aquele que está imerso em sistemas de razão. Assim, a crítica é dependente de uma teoria sobre a imaginação dos sistemas de razão.

O século XVIII estreita mais a indissociabilidade da crítica com a obra de arte, até mesmo na percepção de que o sistema filosófico é uma obra de beleza, de verdade; de tal modo que os problemas da crítica são os fundamentais para a estética (CASSIRER, 1994, p. 368|). A postulação sobre a moralidade e a política não se distingue da reflexão sobre a obra de arte, pois o início da moralidade moderna, e sua preocupaçáo com as formas de vida, depende do problema estético da representação do rosto humano. Nesse sentido, para a crítica, o início da experiência é aestheticus, e os problemas concernentes ao político decorrem da possibilidade desse tipo de vida. Ainda que haja um estreito vínculo entre o destheticus e a obra de arte, o primeiro conceito é o mais amplo. Dessa maneira, todo problema político é estético, pois concerne à possibilidade da experiência da natureza humana, mas nem toda questáo estética será politicamente relevante. Será na obra que a natureza humana reconhecerá a composição de sua experiência de modo mais intenso, porque as atividades da natureza humana são a abertura à experiência e a necessidade instituidora. A moralidade é reguladora desse dualismo de abertura e atividade.

A crítica é uma atividade filosófica inscrita entre atividades filosóficas; não precisamos padecer do mau gosto de a denominar metafilosofia, mas precisamos reconhecer que ela se afirma numa sensibilidade especial ao caráter artístico dos sistemas. Apesar do longo nascimento, é em Bayle que encontramos a figura por excelência do exercício da crítica, e também do crítico. ${ }^{5}$ Ambos, porque seu argumento torna evidente os pequenos retratos ambivalentes do paisagismo de Montaigne, depois porque seu Dicionário Histórico e Crítico assume a postura pictórica de rapporteur e se fiscaliza para não incorrer na atitude de avocat. Por certo, em qualquer enunciação existe a sustentação da voz, o que significa alguma centelha avocat, nem que seja a

\footnotetext{
5 "A crítica é uma arte de julgar. Sua atividade consiste em interrogar a autenticidade, a verdade, a correção ou a beleza de um fato para, a partir do conhecimento adquirido, emitir um juízo [...]". (KOSELLECK, 1999, p. 93).
} 
defesa da crítica, porém, a questão é que o pictorialista é predominante, tal como, em Montaigne, o paisagismo é sempre superior ao fideísmo.

O que é fascinante na crítica de Bayle, e na tradição que ajuda a inaugurar e reforçar, é que tal atividade se dá em bloco. Se a aproximação, ou exposição, a uma experiência se deve ao gosto, em toda a sua ambivalência e atração, pela obra, se toda crítica, por mais política que seja, inicia-se como crítica de arte, ela náo pode se eximir a contemplar algo da confusáo entre os julgamentos morais, artísticos e políticos. Ela, ao mesmo tempo em que não pode confundir os modos da judicação, pois um dos pilares da fundação da crítica é a interrupção à analogia universalis, precisa entender a si mesma como pirroacrobacia. Não só precisa manter todos os objetos no ar, como ter a consciência do porquê um não se confunde com o outro, ceticamente, sem os tornar hipóstases. A crítica se afirma na categoria de verdadeira opositora ao "todas as coisas estão em todas as coisas", que não seja a experiência, pois não se esconde na especialização das disciplinas.

O Dicionário Histórico e Crítico (1695), dá notícia de algumas características da crítica. ${ }^{6} \mathrm{~A}$ primeira delas é a necessidade de inovação formal. A crítica cética inventa uma forma de dizer. A inventividade é percebida no paisagismo pictórico, falar de si e de todas as coisas que se vê, dentre elas, infindáveis crenças e pequenos retratos, na demanda de fabricação literária do gênero do ensaio. Todavia, Bayle não escreve apenas verbetes/ensaio, ele produz uma diagramaçáo para apresentar seus verbetes, existe um cuidado formal para dispor os tipos de nota e a interação que essas têm com o texto: existe uma verdade tipográfica, que antecipa os caligramas. Por isso, podemos concluir pelo movimento de afetação artística, em função do olho sensível à pictorialidade. À crítica cética é impossível deixar de fabricar uma escritura própria ao seu modo de ver; se Montaigne se contentou com a criaçáo de um modo literário à sua expressão, Bayle também o fabrica, mas o faz pela captura da verdade pela tipografia.

Existe relação entre a crítica e a razão, entretanto, a crítica kantiana deturpou essa boa proximidade; nela, de alguma forma, a razáo é externa à crítica e faz dela o seu exercício. A crítica é a expressão temporal de algo que com ela não se confunde. Contudo, a fundação crítica de Bayle é bastante

\footnotetext{
6 "A crítica é um trabalho perigoso, pois, quando ignorados alguns fatos particulares, todos os outros conhecimentos são incapazes de impedir que julguemos mal as coisas." (BAYLE, 1740, p. 128). Se, no começo, a crítica era apenas um sintoma da diferença, cada vez mais aguda, entre razão e revelaçáo, com Pierre Bayle, ela se torna atividade que separa os dois domínios.
} 
distinta; nela, a crítica não se distingue da razão. Dessa forma, se perguntarmos sobre a razão, a resposta será a crítica. Num primeiro sentido, a razão é a suspensão que leva à pictorialidade, depois, consiste na paisagem de crença e seus pequenos retratos, logo, ela se desenvolve e se torna retrato da crença como sistema filosófico. A razão não é nunca ter razão. Nessa acepção é que a tradição crítica diminui o peso da retórica e deposita confiança no ambiente da verdade. A inovação formal crítica concerne à instituição de um ambiente da verdade. A razão é tipográfica. A liberdade é liberdade de prensa. A liberdade é liberdade de instituição sobre o papel. Pode-se dizer que a razão-crítica (usamos as duas palavras com hífen, apenas para dar a ver a indissociabilidade, e a separação como equívoco) tem compromisso com o futuro, mas esse não possui uma substância a ser encontrada pela finalidade, ele não se distingue da manutenção, de um exercício. A crítica se vincula ao futuro em que se possa fazer crítica. ${ }^{7}$

A razão-crítica é uma máquina de guerra (não se confunde com a sátira ou com os libelos difamatórios), que, por existir, conforma o mundo numa certa direção. Dentre os efeitos imediatos está a exumação da religião. À revelação é concedido o mesmo peso de verdade que à crítica, ora, também uma verdade tipográfica. Por essa razão é que os contornos lógicos da crítica cética são também encontrados na religiosidade, pois a verdade religiosa é a fabricação de mundos. Nesse sentido, Montaigne, Bayle e Hume reconhecem que na religiấo se encontra com intensidade o operador humano para instituir sobre o tempo, porém, longe de admitirem o uso teológico da crença, promovem obras de laicização. Não é que na forma "crença” haja religiosidade, mas reconhecem a profunda captura histórica, promovida pela religião com relação a esse operador. A crítica, porque percebe o porquê da crença, não se confunde com o estado, nem tenta. Sua apoliticidade se reduz ao fato de que não há crítica soberana. A crítica participa de um pensamento estético e, pelo seu exercício, critica o Estado, os partidos e as religióes. ${ }^{8}$

\footnotetext{
7 "[...] esse fervor da liberdade que reina na república das letras. Essa república é um estado extremamente livre. Nele só se reconhece o império da verdade e da razão; e, sob os auspícios delas, trava-se guerra inocentemente contra quem quer que seja. Os amigos têm que se proteger dos amigos, os pais dos filhos, os sogros dos genros: é como um século de ferro. Ali, todos são soberanos e podem ser julgados por todos." (BAYLE, 1740, p. 102).

${ }^{8}$ Koselleck, (1999, p. 97) “[...] em Bayle, o crítico só tem uma obrigação: a obrigação com relação ao futuro. Pelo exercício da crítica encontra-se a verdade. A pretensáo de alçar-se acima dos partidos impulsionava o processo para frente na mesma medida em que seu fim não estaria à vista. Na vinculação do crítico com a verdade a ser descoberta residia a autogarantia da crítica."
} 
“Crítica quer dizer distinção.” (ROSELLECK, 1999, p. 105). Mas porque o pensamento consiste, em larga medida, em fazer distinçóes. Todavia, se as distinções são capturadas pela lógica da vitória política, de certa forma a perda de elegância também é perda de verdade. A necessidade, posta por Bayle, de que a crítica esteja fora da lógica da vitória política, dá-se por uma necessidade ontológica: não há teoria da imaginação sem que se veja a pictorialidade da experiência e, pelo rigor estético, o escrito de vitória política olha para o dedo de Crátilo, e náo para o que aponta, sendo, portanto, um escrito ruim. A crítica afeta a política, não porque se preocupe com a vitória, mas pela fala à configuração do mundo. Aquilo que a crítica precisa para existir é acrescentar objetos pictóricos ao mundo. A crítica é crítica de arte, na proporção em que exerce os seus efeitos de modo incidental, posto que é configuradora de mundo, quando bela.

A crítica não relativiza a verdade, mas também não a substancializa. Isso significa que a verdade é um dos conceitos críticos, e que pode ser alcançada. A verdade crítica não é essência, logo, não é vista pela intuição e não se esconde nos objetos. $\mathrm{O}$ estabelecimento da verdade depende, primeiro, da aceitação da visibilidade e recusa da invisibilidade, depois, da fixação de critérios de análise dos observáveis. Contudo, a vedação à invisibilidade não reduz a experiência à sensibilidade, mas à imagem. Dessa forma, existem homologias verdadeiras e falsas. As homologias verdadeiras tomam formas discursivas nas variaçôes dos princípios de composição da imagem, suas cores, e os modos pelos quais explicam os efeitos dos discursos e dos diagramas de crenças na experiência da natureza humana. As homologias falsas podem ser definidas pela ideia de horizonte indistinto: enquanto não se pode enxergar bem a circunscrição dos objetos, parecem concernir a uma mesma figura e, sob delírio, pode-se atribuir invisibilidade à lógica que os organiza. A crítica lida com paciência e otimismo epistemológico com tal opacidade momentânea. Experiências indistintas ou prenunciam um conceito ou um objeto que ainda não foi distinguido. Todas as coisas estão em todas coisas, apenas no que concerne ao pertencimento à experiência e serem possuidoras de composição - tudo o mais é distinto.

A crítica, tendo os elementos de análise da abstração, do retrato conceitual e da paisagem de crenças, para determinar a verdade de um enunciado e, sobretudo, de um valor, procura localizá-la no ambiente imaginativo do qual procede. Não é muito coerente analisar a verdade fora da circunstância da imaginação que nos faz crer nela. A ela concernem também os modos pelos quais a falsificação se contrapóe, enquanto negativo, e a maneira pela qual a 
falseabilidade a modifica. No campo da experiência crítica, é notável o poder de anulação que a inautenticidade exerce sobre a autenticidade-verdade, bem como na força de modificação da verdade pelo falso e pelo falsificado. De alguma maneira, a falsificação pode ser autêntica, uma vez que pode ter efeito de propriedade, de ironia talvez, ou de camuflagem. Assim, a associação entre a falsificação e a inautenticidade é apenas parcialmente verdadeira. À medida que a falsificação toma consciência de sua capacidade transfiguradora, ela passa a se fundir com a falseabilidade. Não podemos ostentar uma falsificação inautêntica, pois, no processo de ser identificada e exibida, sobre ela passa a operar a autenticidade da crítica, antes, como falseabilidade, depois, como o verdadeiro. A crítica busca a verdade dos objetos autênticos em sua enunciação imaginativa e persegue a falsificação, no sentido de operar sobre ela os efeitos do falso, e, consequentemente, da verdade. Apenas o inautêntico falsificado indiscernido é plenamente pernicioso, pois distante dos olhos da crítica.

Em obra não diretamente compreendida no nosso ângulo de abordagem, Lukács (2005) analisa o forte poder de falsificação, ou seja, de tornar indiscerníveis as diferenças entre os objetos, exercido pela filosofia do Dasein e do existencialismo sobre as tradições da crítica filosófica. Lukács, contudo, cede ao rápido apelo de denominar as filosofias do mal-estar acerca da temporalidade de irracionalismos; que, além de ser um apelido preconceituoso e que nada explica, furta-se a investigar a instituição do entendimento pela imaginação. Adorno retomou o ponto de Lukács, e chamou tais formas filosóficas de jargóes da autenticidade (ADORNO, 1989). Contudo, ambos ignoraram a tradição cética de uso da autenticidade como marca distintiva dos objetos, iniciada por Montaigne.

\section{IV}

Duas são as obras de Lukács que abordaremos: Alma e Forma e Prolegômenos para uma Ontologia do Ser Social. Trata-se, respectivamente, do seu primeiro trabalho e do último. Parece que existe uma temporalidade comum ao estilo tardio e à forma de juventude. É coerente defender que o estilo tardio é uma forma de juventude, o que nos leva a um diálogo direto entre esses momentos enunciativos. Lukács é bastante paradigmático do nosso argumento, pois essa ambiência enunciativa não é de nenhuma maneira necessária. Há autores que não têm uma forma de juventude e há aqueles que, mesmo lutando contra a morte para terminar uma escritura, náo manifestam 
um estilo tardio. Tanto o estilo tardio quanto a forma de juventude concernem a um tempo sem tempo. $\mathrm{O}$ ensaio parece ser o modo de escritura que emerge dessa ansiedade. No entanto, ainda que o tempo sem tempo seja o da constituição do ensaio, ele não é natural à autoria, ele precisa ser instituído, mas apenas o é por acidente, um tipo de sorte artística, mas azar pessoal, pois, uma espécie de trauma. À instituição surge o modo, ou seria mais um módulo ansioso, no qual o que precisa ser dito tem um tempo próprio para sê-lo, não só no que concerne ao mundo, porém, ao autor. $\mathrm{O}$ ensaio talvez seja a única forma defensável de autoria, pois nele o autor se percebe esfacelado diante da experiência que o circunda, mas, mesmo assim, precipita-se a dizer, por medo diante do silêncio eterno das homologias? .

A forma de juventude possui os mesmos elementos do estilo tardio, mas a intensidade sofre variação. Nas duas manifestações, percebemos: (i) angústia acerca do conseguir dizer, (ii) angústia sobre a possibilidade de dizer e (iii) angústia a respeito da possibilidade de levar a escritura até o final. $\mathrm{Na}$ forma de juventude, uma vez instituída a angústia, o enunciador não sabe se conseguirá ser capaz de dizer no momento certo, pois ainda inventa o seu corpo autoral, mas percebe que a sua "descoberta" conceitual não pode esperar para ser revelada; o enunciador sente nos ossos que pode ser tarde demais para o mundo. No estilo tardio, apesar das angústias, ele tem seu corpo autoral formado, mesmo que não sob sua forma derradeira, e sabe que o mundo foi preparado para ouvi-lo, ou que a audiência, de algum modo, aparecerá, mas não sabe se é tarde demais para si mesmo. A forma de juventude possui uma desmesurada arrogância de gênio, todavia, um profundo altruísmo, no que concerne a entregar, fazer algo, pelas coisas. $\mathrm{O}$ estilo de maturidade, pelo gênio formado e seguro de si, não possui nenhum altruísmo, mas o profundo egoísmo acerca do terminar de dizer, por si.

É simples perceber que a forma de juventude é uma velhice precoce, e que o estilo de maturidade é uma espécie de grande saúde. Podemos afirmar que essa troca prende os dois momentos ao ensaio, sendo ele derradeiro e vital. O ensaio é o que liga as instâncias às mesmas dificuldades autoimpostas. Contudo, tais dificuldades não são frívolas, mas estratégicas para o evitamento das negaçôes performativas e, consequentemente, contra as falsificaçóes. O

\footnotetext{
9 Ainda sobre a ideia de estilo tardio, um trecho do poema em prosa The Monument de Mark Strand (2010, p. 131): "Se eu fosse morrer agora, Eu mudaria o meu nome para que parecesse que o autor da minha obra ainda fora vivo. Náo, náo faria. Se eu fosse morrer agora, Eu seria apenas uma piada, uma cruel piada da fortuna. Se eu fosse morrer agora, seu maior trabalho permaneceria para sempre incompleto. Minhas últimas palavras seriam 'Não o termine'."
} 
ensaio crítico, por sua angústia, aborda a política sempre de modo incidental, por seus efeitos colaterais em obras de arte, ou temas que se apresentam como artefato; desse modo, a lógica da vitória se mantém distante do ensaio. Montaigne foi o primeiro a perceber a frivolidade presente na tentativa de encontrar unidade nos ensaios. Parte da vitória à lógica da vitória retórica se deve ao fato de que o ensaio é uma forma de fácil adesão, mas de fraca fidelidade aos usos do hermeneuta.

A forma de juventude precisa muito dizer, mas à escritura analítica parece fazer faltar sentido. Por essa razão, o ensaio é a forma de uma angústia que se faz expressiva. O ensaio fala pela análise da colateralidade de seu objeto e torna a enunciação ainda mais alta pela expressão. Pela forma de juventude, existem múltiplas inovaçóes formais sob a formalidade criada pela angústia enunciativa. Em função do tempo sem tempo, pela angústia, o ensaio rotaciona numa espécie de pequenas suspensóes do tempo, de sorte que a leitura do ensaio necessita não só de preparo filosófico, mas gosto para ver a sua duração.

Por outro lado, o estilo de maturidade náo precisa se esforçar para encontrar expressão, pois a sua angústia se acende diante da morte. Porém, não é um medo convencional diante da morte, pois esse é abandonado desde a infância do ensaio - basta percebermos o humor diante da morte de Montaigne e de Hume -, mas uma angústia de quem não teme a morte, mas ainda tem o que dizer. $\mathrm{O}$ medo se dá apenas pela projeção de não poder escrever a última frase. $\mathrm{O}$ estilo de maturidade evita o excesso de inovação formal praticado pela juventude e não se preocupa com a expressão, porque essa lhe é evidente. A angústia se dá em ser interrompido pelo tempo. Nesse sentido é que o estilo de maturidade é saborosamente repetitivo. Nele, o corpo autoral se faz fraco e, por isso mesmo, sua beleza se impóe. $\mathrm{O}$ autor parece ceder espaço à experiência que o inventou enquanto enunciador. $\mathrm{O}$ estilo de maturidade é o mais importante, pois, antes de ser uma fala-conceito, concerne a uma palavra-experiência a deixar de ser conceito. Mesmo que o escrito de maturidade náo tenha a ontologia como objeto, se o autor possui um estilo de maturidade, sua fala será ontológica por necessidade, visto que, no momento em que sair do ser para voltar ao tempo, estará morto.

Podemos afirmar que o estilo de maturidade precisa da forma de juventude para distrair a sua angústia. Antes de tudo, porque é a segurança da forma que permitirá ao estilo de maturidade manejar com naturalidade a expressão ontológica. Depois, a angústia em não terminar o escrito, em ser 
levado pelo tempo, é aplacada pelas angústias sobre o conseguir dizer e sobre o tempo para o mundo. Mas são apenas distrações, simulacros de angústia, porque o estilo de maturidade é forte pelo desabamento do autor e pelo fato de que, quanto mais experiência ele mostra, menos mundo tem. A morte seria a vida sem crenças, digamos que o estilo de maturidade é o que de mais próximo disso pode a natureza humana chegar. Ora, o estilo de maturidade se associa à forma ensaística da juventude por compartilhamento de angústias inerentes ao tempo sem tempo e, se não nos é dado viver sem julgar e sem respirar, parece óbvio que a proximidade da morte dê alguma clareza metafísica ao crítico. Seu discurso permanece colateral, porque segue a mesma estrutura da experiência - o ente se confunde com seus traumas -, todavia, ao invés de se centralizar por sobre obras de arte, ou artefatos para atingir a política de modo incidental, anulando a dinâmica da negação da lógica da vitória, centra-se na pictorialidade mesma do ser.

$\mathrm{Na}$ obra de Montaigne, o ensaio - que, como destacamos, assume a pictorialidade descritiva da paisagem de crenças, com pequenos retratos de homens comuns - é, ao mesmo tempo, forma de juventude e estilo de maturidade. Na obra de Bayle, a pictorialidade do retrato e o compromisso com a verdade crítica o fazem assumir um estilo entre a juventude e a maturidade, digamos que seja a maturidade mitigada de todo aquele que possui um projeto ilimitado. A morte não é encarada, e também não serve como expressão, pois é espantada pela disciplina e pelo dever. Hume, tal como Lukács, apresenta uma diferença marcada entre a forma de juventude e o estilo de maturidade, inclusive suas obras de transição servem de contraste para a estrutura; o Tratado da Natureza Humana é uma vertiginosa obra de juventude, de escrita angustiada e expressiva (ainda mais se comparada ao estilo um pouco frio de suas investigaçóes - mesmo que o humor esteja sempre presente), ao passo que corrige seus ensaios até o momento da morte, fazendo anedotas sobre como conseguiria mais tempo com o barqueiro do esquecimento.

Adorno percebe que a pictorialidade do ensaio é dependente da capacidade que possui de autorreflexão. A crítica por ele conduzida depende da modificação formal, no momento da enunciação do conteúdo. A forma do ensaio demanda um meio que se metamorfoseia enquanto fala. A percepção de si realiza a nova voz expressiva da forma de juventude, mas também serve como antídoto ao julgamento biografista contra o ensaio, pois existe uma densidade de acumulação histórica entre os ensaístas. Ao se perguntar pelo sujeito do ensaio, tem-se como resposta uma bela polifonia despertencida, 
porque as angústias no ensaio não são as angústias do ensaísta, mas as da forma. O ensaio é escrito em muitas primeiras pessoas: para ser ensaio, o ensaísta deve falar como Montaigne, Bayle e Hume, e falar como si mesmo, de modo indiscernível às outras vozes. Se o ceticismo moderno se distingue do antigo pela aceitação e habitação da diaphonia, o ensaio é a voz polifônica desse fato. Entretanto, a autorreflexão do ensaio é sobretudo formalista. $\mathrm{O}$ ensaio se autovislumbra como sujeito, mas também, como frisado, enquanto forma pictórica. E, nesse sentido, a distinção completa entre forma de juventude e estilo tardio não é possível. $\mathrm{O}$ ensaio se vê pictórico, logo, ele vislumbra as cores e as formas de suas letras, razão pela qual a cultura do ensaio não se distingue da ontologia. A metafísica se confunde com o ensaio crítico, pois o apego estreito do ensaísta, com a experiência do ensaio, faz com que o tema da composição da experiência seja a perspectiva a partir da qual a experiência como um todo seja percebida. ${ }^{10} \mathrm{O}$ ensaio é uma filosofia da experiência do ensaio na experiência do mundo. Dessa maneira, a historicidade do ensaio é dedutível da própria forma do ensaio. No ensaio, não se trata apenas da historicidade e fragmentaridade da verdade; nele, esses elementos são efetivamente mostrados no modo pelo qual o ensaísta experiencia a forma que inventa, e na qual é inventado. ${ }^{11}$

O ensaio é uma forma de juventude pouco tolerante com a inexperiência, porque, como ressaltamos, ele surge em Montaigne, que o inventa, ao mesmo tempo, como forma de juventude - uma grande saúde - e estilo de maturidade. O ensaísta precisa pressupor toda a história do ensaio, na sua primeira letra. Se a forma de juventude for objetivada por um jovem, ele precisa ser um leitor nervoso, para envelhecer em espírito e poder inocular, desde sempre, em suas enunciaçóes, algo do estilo de maturidade que ainda

\footnotetext{
10 "A relação com a experiência - e o ensaio confere à experiência tanta substância quanto a teoria tradicional às meras categorias - é uma relação com toda a história; a experiência meramente individual, que a consciência toma como ponto de partida por sua proximidade, é ela mesma já mediada pela experiência mais abrangente da humanidade histórica; é um mero autoengano da sociedade e da ideologia individualistas conceber a experiência da humanidade histórica como sendo mediada, enquanto o imediato, por sua vez, seria a experiência própria a cada um. O ensaio desafia, por isso, a noçấo de que o historicamente produzido deve ser menosprezado como objeto da teoria. A distinção entre uma filosofia primeira e uma filosofia da cultura [...] não é sustentável."(ADORNO, 2003, p. 26).

11 "É por isso que o ensaio não se deixa intimidar pelo depravado pensamento profundo, que contrapóe verdade e história como opostos irreconciliáveis. Se a verdade tem, de fato, um núcleo temporal, entáo o conteúdo histórico tornou-se, em sua plenitude, um momento integral dessa verdade; o a posteriori tornou-se concretamente um a priori [...]." (ADORNO, 2003, p. 26).
} 
não descobriu. Apenas depois de se ler Montaigne, Bayle e Hume é que se pode escrever ensaios, sendo condição necessária, mas não suficiente.

A crítica não tem fundamento, pois o ensaio não dialoga com o infinito, dele se desvia - o desvio formal é um modo da refutação -, não tendo um começo ou um fim, mas uma densidade enunciativa para acontecer. A convicção do ensaísta não possui reservas ou estoques temáticos, ele dá tudo o que tem, e o faz da única forma possível, sem guardar fôlego para a volta, não tem começo e não tem fim, porque não consiste na defesa de um sistema, porém, de um pensamento sistemático para a criaçáo de objetos pictóricos. Nesse sentido, o ensaio é um meio lento de interferência na ordem das coisas, mas seus efeitos são perenes. O ensaio crítico demora para ser entendido e, por isso, o objeto pictórico que representa abriga objetos acessórios revelados em cada desvelamento da visualidade. Isso ocorre, porque o ensaio é retalhado, mas não pode ser retalhado. Se a interpretação assim promove, ela simplesmente deixa de ver um ensaio. Digamos que o ensaio sacrificou a sua capacidade de vitória em função da sua capacidade de mostração. $\mathrm{O}$ ensaio não precisa de sistema, contudo, diante do sistema, ele se faz, por vezes, de crítica ao sistema. ${ }^{12}$

Seria um pouco tolo admitirmos que o método do ensaio é não ter método, ainda que saibamos que essa será a resposta da crítica dialética. Mas negar a tese como resposta ainda é pouco para entender o ensaio como nosso intenso pensamento. Porém, se não tem método, o que tem? A escritura do ensaio se dá por linhagem densa. Quão mais próximo da tradição e quão mais capaz de reinventá-la. O primeiro esforço do ensaísta à procura da compreensão do estilo tardio da forma de juventude consiste na habitação. Todavia, não se trata de uma habitação retórica, uma armadilha de passarinho, para afastar a imagem, mas uma morada única. O morador da habitação, pela experiência do ensaio, mostra em sua voz pelo que passou; o ensaio, além de buscar reconfigurar os critérios da verdade, e acertá-los também, deve transmitir uma sensação de verdade, contida na convicção densa da voz do ensaísta. O leitor do ensaio tem a sensação de que o ensaísta viu um fantasma. E da fantasmagoria convicta se inicia a deposição de um objeto pictórico por intepretação do ensaio. Nesse sentido de habitação é que podemos concordar com Adorno (2003, p. 27): “O pensamento é profundo por se aprofundar em seu objeto, e não pela profundidade com que é capaz de reduzi-lo a uma

\footnotetext{
12 "O ensaio também não deve, em seu modo de exposiçáo, agir como se tivesse deduzido o objeto, não deixando nada para ser dito. É inerente à forma do ensaio sua própria relativização: ele precisa se estruturar como se pudesse, a qualquer momento, ser interrompido. $\mathrm{O}$ ensaio pensa em fragmentos, uma vez que a própria realidade é fragmentada [...]." (ADORNO, 2003, p. 34-35).
} 
outra coisa." Donde, a despeito das vontades de Adorno, parece-nos necessário ter de um lado o pensamento profundo, e o seu infinito, e o pensamento que se aprofunda, e a sua circunscrição. Enquanto esse é um pensamento que, em alguns momentos, é profundo, porque, pelo gosto, é passível de se aprofundar na temporalidade de um objeto, o outro é apenas um pensamento profundo, porque nasce sistema e, portanto, não precisa se fazer sistemático. O pensamento que se aprofunda, o pensamento que é profundo, habita o ensaio, enquanto o outro se afirma na negação do fragmento. O pensamento que se aprofunda não é profundo sempre, como o pensamento profundo, mas profundo às vezes. E tal oscilação da profundidade acarreta em uma concepção completamente distinta do que é o profundo. O profundo verdadeiro, circunscrito, não é profundo, no entanto, aprofunda-se, estando, por vezes, no raso, mas habitando para descer as escadas. O profundo de mentira está sempre numa forma de raso a que chama de fundo, não desce escada, evita qualquer aprofundamento no objeto, pela escolha, pretensamente a priori, de alguns a serem defendidos com gravidade. $\mathrm{O}$ ensaio existe para a profundidade circunscrita, e não para a outra.

Apenas o ensaio aborda o ensaio, dentro ele está todo fora. Noutras palavras, todo ensaio é ensaio aberto. Nesse sentido, a mera existência do ensaio é opositora. Talvez se possa dizer que por instituir por modos incidentais, por se desviar do pueril e da apreciaçáo frívola, o ensaio seja um gênero implicante. Mas essa sensação pode ser aplacada, se levarmos em conta a necessidade de uma dinamicidade interior, mais acelerada que o mundo, e uma intensidade expressiva, muito superior às outras vozes. $\mathrm{O}$ ensaio não tem paciência com apreciação ou escrita frívolas, por seu compromisso com as dificuldades do incidental; as questóes do ensaio são matéria de vida ou morte. Aquele que suporta o anacronismo na voz não tem tempo a perder. Por essa razão, o ensaio se opóe à regularização metodológica do mundo ou das disciplinas intelectuais. Em virtude de habitar a composição, o ensaio sabe que a imagem não se reduz a regularidade. E, por outro lado, o ensaio também se opóe à opacidade enquanto filosofia, àquilo que Adorno denominou jargão da autenticidade e que julgamos apropriado chamar de filosofia da invisibilidade, uma vez que é um engano permitir que a autenticidade se confunda com o jargão, porque está na gênese mesma do ensaio. No jargão, a autenticidade se presta a uma filosofia sem critérios e de fundamentos invisíveis e ortodoxos. ${ }^{13}$

\footnotetext{
13 "Apenas a infração à ortodoxia do pensamento torna visível, na coisa, aquilo que a finalidade objetiva da ortodoxia procura, secretamente, manter invisível."(ADORNO, 2003, p. 45).
} 
A autenticidade, contudo, concerne ao pensamento interno da expressão e sua presença nos objetos. É a autenticidade que possibilita dizer a verdade, e, na análise, é ela que permite à crítica distinguir a verdade, e os processos de falseabilidade, da falsificação. Adorno percebeu que a verdade não pode ser tautologia, mas não viu que é a autenticidade que impede o dialelo. Não só Adorno recusou a autenticidade, por horror ao jargão, como recusou a regularidade, por horror à burocratização da verdade, entretanto, fazendo-o, não conseguiu escapar ao invisível e à tola distinçáo, de todo muito diferente daquela dos gregos, hegeliana entre imagem e conceito. ${ }^{14}$

A crítica dialética foi despertada pelo profundo interesse de Hegel pelas imagens, mas herda igualmente o dualismo entre a verdade, concernente ao campo das essências, e o falso, aos simulacros. A crítica dialética não larga da opacidade e do invisível, atrelando a esse a superioridade conceitual para reger as imagens. Mas essa cegueira pontual do conceitualismo da crítica dialética tem efeitos para além da nociva hierarquização da dinâmica conceito e imagem, o mais relevante é o fetichismo da crença. Por não ser capaz de interrogar a natureza da imagem com a mesma atenção que dedica ao conceito, a crítica dialética planifica a crença, denominando-a, de modo genérico, como ideologia. O ensaio não é "crítica da ideologia", ele é a crítica da ideologia também, porém, justamente porque não separa a crença do conceito, de modo a impedir que seja feita em fetiche, analisa-a como parte essencial da ideologia. A ideologia é um tipo específico da crença. Ainda que nem toda crença seja um conceito, todo conceito é crença, posto imagem. Esta é a boa nova ignorada pela crítica dialética, ao aceitar irreflexivamente a operacionalização do ceticismo promovida por Hegel. O ensaio, na perscrutação de si, e na descrição de seus objetos, deve se ver não só como um gênero formal, mas como uma forma pictórica específica. "[A] cor própria [do ensaio] que náo pode ser apagada” não deve se render a ser compreendida como metáfora da expressão, mas como matéria de seu exercício (ADORNO, 2003, p. 36).

O ensaio, ao exercer a crítica, é uma ação interpretativa sobre um objeto e, sobretudo, sobre um plano de disponibilidade pictórica. Não há acréscimo de significação sem alguma brecha a ser percebida. Pode ser que, em algum momento da história da humanidade, a regularidade evite todas as

14 "Se a verdade do ensaio move-se através de sua inverdade, entâo ela deve ser buscada não na meia contraposiçấo a seu elemento insincero e proscrito, mas nesse próprio elemento, nessa instabilidade [...]. Quando o espírito deseja mais do que a mera repetição e organização administrativas daquilo que já existe, ele acaba abrindo o seu flanco; a verdade, fora desse jogo, seria apenas tautologia." (ADORNO, 2003, p. 41). 
formas de interpretação e o ensaio morra. Mas parte do desafio desse gênero é preservar condições de continuidade de seu exercício. Num certo sentido, a preservação de alguma lacuna nas obras e na experiência. E por que não alguma disponibilidade nos espíritos? Sendo assim, o ensaio recusa a separação entre a imagem e o conceito - náo para compreender a si mesmo como obra -, para, dentre outras razóes, valer-se da inteligibilidade que a regularidade dá à imagem, e manter a regra em seu devido lugar. A regra não é mundo, mas atributo de clareza. Se o ensaio é imagem a interpretar imagens, e se não pode ser visto como obra, ele se percebe enquanto preenchedor de lacunas, não pela regularidade, mas pelo acréscimo de significação. Dessa forma, a interpretação trazida pelo ensaio é, no seu início, um objeto pictórico a se encaixar em lacunas da obra, sendo, portanto, mimético. Embora autônomo, o ensaio se mimetiza para se parecer obra, contudo, essa condição deve ser superada para que se faça objeto. ${ }^{15} \mathrm{~A}$ interpretação não inicia seus efeitos de transfiguração sem se parecer com o objeto interpretado, e sem que adquira, no horizonte, sua própria autonomia enquanto objeto. Antes de tudo, o ensaio fala a língua do outro, a das cores - discurso -, escritura sobre a qual se debruça, para só daí remontar o sentido do plano pictórico que passa a habitar. Aludiríamos, pois, à habitação polifônico-pictórica da diaphonia da crítica a praticar o ensaio. O objeto pictórico praticado - e predicado - no ensaio crítico, muda de forma e coloração, e tal na propriedade mesma do exercício. Por essa razão, o ensaio faz objeto autêntico que se dá a ver, em seu começo, como métis do discurso escolhido, mas, quando bem-sucedido, mostra-se como renovação da planaridade pictórica (ADORNO, 2003, p. 19). A regularizaçâo do ensaio, ou seja, a desistência quanto à inovação formal, e perda da autorreflexáo pictórica, faz do ensaio uma escrita frívola, e que pode ser definida como "falsa profundidade" ou "superficialidade erudita".

Adorno repreende Lukács, por esse ter visto no ensaio uma forma artística, ainda que primitiva, se comparada com a "sua irmã, a literatura", marcada por certa indistinção com a moral. Por outro lado, Adorno náo endossa a perda do estético na enunciação crítica, mas não consegue perceber para além da negatividade do ensaio. A irreversibilidade da "separação entre ciência e arte" é vista por ele como de inevitável consciência à consciência do ensaio. No entanto, não precisamos de excessivo espírito de conciliação para ver um pouco de verdade em Adorno e Lukács. Como o ensaio se escreve

15 "Nada se deixa extrair pela interpretação que já não tenha sido, ao mesmo tempo, introduzido pela interpretação.” (ADORNO, 2003, p. 18). 
como ciência do espírito de densidade expressiva e, por esse motivo, inovadora nos modos de dizer, o ensaísta não sabe dizer sem certa prosa poética, mas só pode ser lido na qualidade de objeto artístico. Em função de lhe ser vedada, por moralidade, o imediatismo moral, apenas a leitura artística permite os efeitos de moralidade difusa, estratégia essencial do gênero no evitamento da lógica da vitória. Por não ver a natureza imagética do conceito, Adorno restou preso à dialética na natureza. Ele crê que a conceitualidade do ensaio afirma a dialeticidade essencial da experiência. Ele julga que a dialética é o que une o conceito à imagem. Todavia, a experiência não é dialética, mas pictórica. A dialética é um operador da pictorialidade, uma tesoura que auxilia a desencobrir a crueldade.

\section{V}

Pensemos, pois, que o percurso do ensaio faz movimento de realização de objetos, os quais, contrapostos, juntos, mostram o sentido amplo do gênero. Dessa maneira, ver o ensaio de Lukács é uma visada que se faz olhando para Adorno. Trata-se da capacidade de rigor descritivo de Bayle, portanto, olhamos Montaigne ao lado de Lukács e Adorno, tâo solenes quanto um verbete, hesitando ao conferir as ligaçóes estritas, para não matar as mostraçóes realizadas pelo amparo de um autor sobre o outro. Nos ombros dos gigantes restada, essa transfiguração do retratismo composto com o paisagismo e a objetalidade abstrata, pois os autores passam a funcionar como objetos abstratos a serem compostos por montagem e o sentido geral da mostração é obtido por uma costura de sentido que penetra nos objetos ao mesmo tempo em que os une. Dá-se, nessa medida, uma dupla articulação de sentido, aquele interno da obra dos autores e a conjugalidade de uma ponte entre eles. Nesse caso, Adorno precisar restar nos ombros de Montaigne, Lukács etc. para elaborar o seu sentido, enquanto objeto da montagem, ao mesmo tempo em que revela a sua infidelidade. Essa é a evidência da natureza tipográfica e objetal da verdade do ensaio crítico.

No ensaio "Da Natureza e Forma do Ensaio", o aspecto da inovação formal, uma vez partícipe da necessidade enunciativa, coloca-se desde pronto por se tratar de uma carta. Escrita a Leo Popper, não é nem uma carta de verdade, nem uma carta entre intelectuais e nem a recomposição da carta, como se pode ver em Goethe ou Hoffmann. Trata-se, pois, de uma cartaensaio. Lukács revela bem o problema do ensaio: ele concerne a uma verdade 
tipográfica diretamente ligada à liberdade da enunciação necessária, ele consiste numa forma de arte de logicidade mais rigorosa do que a científica. Nesse sentido, ele é uma arte, porque sobretudo uma forma. ${ }^{16}$

Entretanto, o crucial na diferença entre uma obra de arte e o trabalho científico é talvez este: enquanto um é finito, o outro infinito; enquanto um é fechado em si, o outro é aberto; enquanto um é intencionado, o outro é significativo. Enquanto um - e agora estamos julgando as consequências - é incomparável, a início e ao fim, o outro é tornado supérfluo por uma melhor conquista. Para colocar de modo resumido: enquanto um tem forma, o outro não. (LUKACS, 2009b, p. 92-93). ${ }^{17}$

O ensaio atende a um rigor de escritura e de verdade que se vale dos mecanismos compreensivos e de distinção, mas, ao contrário da ciência, o ensaio, em sua tarefa crítica, deve mostrar o modo pelo qual a verdade é construída tipograficamente e náo o oposto. A ciência se depreende do ensaio, enquanto manifestação mais leve do espírito, posto poder se conciliar com o infinito, enquanto opacidade ortodoxa, com o aberto, enquanto regras do campo epistêmico, e com a refutação, enquanto medida de interrupção. A verdade no ensaio faz com que o ensaio crítico seja continuamente refutado, se posto como objeto à refutaçáo, a angústia interna a ele náo se interrompe jamais, e com que não haja uma diminuição histórica pela obsolescência, mas acúmulo diafônico. A cada novo objeto sobreposto, nesse conjunto de verdades humanas, mais capaz deve ser o novo gosto, para saber ouvir e distinguir. Posto não ter angústia, a ciência não tem necessidade - e quando tem, exige uma forma de rigor artístico - e o ensaio, que é artístico, porque tem forma e ciência, porque também é público, apenas inicia a sua atividade a partir de uma necessidade política. O grande ensaísta faz algo que

[...] precisa ser ciência, mesmo quando a sua visão da vida transcende a esfera da ciência. Por vezes, o seu voo livre é constrangido pela inacessibilidade dos fatos da coisa bruta; por vezes, perde o seu valor científico justamente por isso; afinal, a visão, porque precede os fatos, pode utilizá-los livremente e arbitrariamente. (LUKACS, 2009a , p. 29).

\footnotetext{
16 "Eu quero tentar definir o ensaio do modo mais estrito possível, precisamente o descrevendo como uma forma de arte.” (LUKÁCS, 2009a, p. 17)

${ }^{17} \mathrm{O}$ mais interessante é que Lukács não faz essa necessária distinção, pelo menos não com essa clareza, no seu lugar de direito, que seria o ensaio sobre a natureza e forma do ensaio.
} 
Assim, o ensaio parte de um ensimesmamento provocado pela urgência histórica, onde a maturidade e a juventude se encontram, mas se institui enquanto objeto público inultrapassável e de refutação relativa. A relação entre ensaios é de revelação contígua, de sentido por composição de vários objetos ensaísticos e de revolta. Porém, entre ensaios, não há ultrapassagem ou superaçôes. O ensaísta, ao contrário do cientista, não tem o benefício de ter a sua verdade ou falsidade relativizadas. A experiência do ensaio é aquela para a qual Hume imagina a sua ciência da natureza humana, a ciência; no sentido restrito, é dela apenas uma parte, menos rigorosa.

Podemos sustentar que o ensaio é a imagem do espírito que se concebe enquanto imagem. O ensaio crítico torna explícita, na concepção descritiva, a ordem da pictorialidade e a percepção de que a montagem é um princípio ativo da verdade tipográfica. Por essa razão, Lukács distingue dois tipos de realidade do espírito, a vida e a vivência. Aquela é o momento de contemplação do tipo no espaço sem tempo, enquanto esta é a açáo do tipo no tempo sobre o espaço. Na verdade, tal dualidade é o que se pode denominar experiência da verdade tipográfica, em sua passividade crítica, uma vez que o ensaio pressupóe um leitor, e sua atividade é desencadeada pela necessidade política. A dualidade entre a vida e a vivência do tipo também pode ser transposta para a compreensão do gosto, pois a distinção entre os tipos não é evidente para um espírito sem gosto. Se a verdade tipográfica concerne à experiência do tipo, distingui-la diz respeito a um gosto no tipo. A vida, em sua passividade, em sua duração, é o plano sobre o qual o gosto se aprofunda para ser capaz de aprender a distinguir. A expressão necessária se dá desde o gosto (LUKACS, 2009a, p. 10).

A verdade tipográfica possui a sua imagem, a sua vida, sobre a qual o gosto se aprofunda, e a sua significação, a sua ação, sua capacidade instituinte, aquilo que marca um ponto sobre o qual se pode perscrutar distinçóes verticais. Porque a imagem é uma imagem-vida, ela se torna disponível à contemplação, ao mesmo tempo em que emana uma forte significação, vivendo. Nesse sentido é que da perspectiva da imagem só temos objetos, mais vívidos do que os outros, e do ponto de vista da significação, temos sempre relaçóes entre objetos. Por essa razão é que não faz muito sentido fazer questóes à imagemvida, porque não muito se pode perguntar para objetos, por assim dizer, puros, mas há muito a se indagar para as relaçôes. ${ }^{18}$

18 "Isso é também porque a poesia não sabe nenhuma questão: não se endereça questôes para objetos puros, apenas para as suas relações [...]” (LUKACS, 2009a, p. 20). 
A linguagem de uma imagem sólida é de pura literalidade e a da significação procura correr atrás dos efeitos produzidos pela agressividade literal. Mas não cabe ao ensaio crítico sacralizar a imagem, a centelha cética do gênero, da forma a buscar a forma; fala sempre mais alto do que a defesa do invisível, tout court, ou pela ortodoxia, nisso cabendo à significação estrangular a imagem, para, se não levá-la ao suicídio, forçar que entregue seu princípio compositivo, o modo estrutural pelo qual orientará as ligaduras de significação. O ensaio crítico vê na imagem-vida uma eterna transparência até chegar ao princípio de montagem e, mais além, ao de composição. Lukács assinala que o ensaio crítico busca a desimagem das imagens. ${ }^{19}$

Lukács, todavia, adverte-nos de que a separação entre imagem e significação é uma abstração, pois não há imagem que não estabeleça relações. Não há significação que não provenha de uma imagem que a emane. E, se podemos vincular a imagem à vida e a significaçáo à vivência, restará claro que existe uma preparação instituinte, no momento contemplativo do crítico a fomentar o tipo do ensaio. A vida é mais leitura da verdade, enquanto a vivência tem mais que ver com a escritura. Uma vez que o ensaio é um gênero heterodoxo, ignora as origens invisíveis, de sorte que nele vemos constantemente a vivência preceder a vida, porque só é possível desde a imagem. Ao transpormos esses comentários para o tipo, perceberemos que a tipografia é um exercício da vivência contemplativa do tipo. A circularidade entre a grafia e o tipo só é interrompida pela ontologia da composição, aquele momento em que olhamos o tipo e vemos, não a sua significação, diretamente relacional, mas a sua cor e a profundeza com que se inscreve. Apenas na ontologia o tempo é um ponto de aprofundamento do gosto, e o espaço é o problema central, posto ser aquilo que se faz disponível à cor, sendo cor si mesmo, e no que a instituição se aprofunda.

Ainda que a crítica seja motivada por uma necessidade enunciativa prioritariamente política - aquilo que une a forma de juventude e o estilo de maturidade, na busca de vencer o cedo demais e o tarde demais, próprios da relação entre a enunciação e a política, e de preferir o cedo demais, sob o riso de ingenuidade, ou o esforço de último sopro, ao tarde demais -, ela costuma se deter em objetos políticos, talvez pela intensidade que se pode aprender na análise. Esse aprendizado envolve uma dificuldade: a expressão de uma experiência intensa sempre falseia a experiência. Por esse motivo, a

19 "[...] mesmo Sócrates deve falar em imagens sobre "seu mundo sem forma", seu mundo no lado avesso da forma, até mesmo a germânica desimagem é uma metáfora.” (LUKÁCS, 2009a, p. 20-21), 
crítica precisa buscar o conceito e a composição, neles habita a autenticidade do gênero. A falseabilidade, sob risco de pantomima, deve ser acessória (LUKACS, 2009a, p. 23).

Lukács argumenta que o ensaio se distingue da política, pois essa faz da forma o seu destino, enquanto o ensaio teria o seu destino da forma. Observa ainda que o "[...] destino não é para ser encontrado na escritura dos ensaístas." A forma é, portanto, a elementaridade ontológica do ensaio. ${ }^{20} \mathrm{Se}$ o destino aparece na poesia, o ensaio é antecedido pelo destino. $\mathrm{O}$ destino aparece na poesia, porque nela o destino vem depois, mas no ensaio, o destino não aparece, porque ele vem antes. Aquilo que na política é tematizado, no ensaio é móbil da inovação formal. O destino, nesse caso, pode ser definido pelo ocaso dos dias, pela agrura do existir, que permite ver a vida-imagem e nela se aprofundar, ao mesmo tempo em que se é levado por significaçóes e sofrimentos.

A política não expressa forma, mas destino. $O$ ensaio crítico não expressa destino, mas forma. Nesse sentido, a forma é a realidade da verdade tipográfica, o modo pelo qual se pode endereçar perguntas à vida-imagem e adentrar na composição como resposta. Nada melhor do que ter o destino diante dos olhos, para endereçar perguntas à vida. Por essa razão, a crítica política endereça perguntas a obras de arte, porque nelas a intensidade é maior. Consiste em perguntar às obras sobre a história. Ou seja, perguntar à vida sobre o tempo. ${ }^{21}$ Assim, é fácil perceber o porquê de a necessidade crítica ser provocada pela política, porque o ensaísta se interessa pela vida e a política é o que mais a desafia. Pode-se dizer que o crítico é, ao mesmo tempo, realista e irrealista ou, melhor dizendo, que o seu apego à vida o faz irrealista a ponto de abarcar a realidade. $O$ início da perscrutação crítica, o vislumbramento da imagem, porque prontamente cético, vai ao fato sob a certeza de sua não naturalidade, todavia, tal investida se dá pela única evidência não empírica do ceticismo, a pluralidade nela mesma. Se a pluralidade é uma condição, o fato não pode ser mais do que um momento de unidade, inventado por algum outro foco de pluralidade. O crítico vai ao fato e o atravessa, para encontrar

\footnotetext{
20 "Forma é sua grande experiência, forma - como realidade mimetizada - é a imagem-elemento, o verdadeiro conteúdo vivo de seus ensaios.” (LUKACS, 2009a, p. 23).

21 "Mais tarde, a crítica se tornou o seu próprio conteúdo, a crítica passou a falar somente de poesia e arte, porque não teve a sorte de conhecer Sócrates [...]." (LUKACS, 2009a, p. 31). Lukács percebe que o ensaio pode não aludir a obras, mas se faz da enunciação algo de não necessário, torna-se apenas um livro sobre livros. A principal razão para nâo escrever uma crítica é para tornar um livro mais fácil de ser lido. Um ensaio nẩo é suplência.
} 
o sistema de crença que o faz. A realidade é o fato, pertencente, por sua vez, à irrealidade da crença. Ninguém sabe o que pode uma crença.

A crítica é politicamente despertada pela artificialidade do fato, tal como quando Marx vê que o fato judeu ocidental se sustenta sobre o sistema de crenças que inventa o judeu europeu, e precisa da exemplaridade da vida, para ser capaz de descrever as instâncias tipográficas da verdade. O crítico, ao endereçar questôes à vida, motivado pela necessidade política, percebe que dela só tem expressão. E seu desafio passa a ser inventar uma forma que abrigue a expressão, falseando-a por inafastabilidade, mas nunca a falsificando. $\mathrm{O}$ crítico atende a uma rigorosidade mais do que científica, pois sua busca pela verdade não é estancada pelos critérios públicos de uma área de conhecimento; a medida da busca crítica por expressão é a intensidade da necessidade política que o fez escrever, o seu limite é dado por sua afetação moral. O ensaísta apenas poderá interromper o aprofundamento numa expressão, no momento em que se sentir satisfeito, desde que se perceba portador de uma suficiente intensidade da verdade.

A escolha do crítico pelas obras de arte, segundo Lukács, deve-se ao fato da expressão artística facilitar o caminho, visto que reúne um grande número de questôes num só lugar. Nas obras de arte, a experiência é mais objetiva. A tarefa do crítico é dar forma à expressão. Ao perguntar à vida-imagem sobre o tempo, ele tem como resposta um conjunto de expressóes, às quais é preciso dar uma forma, para se instituir sobre o tempo. A crítica, ao criar objetos pictóricos, institui sobre o tempo marcos de significação. A crítica faz com que a vida não esteja mais aquém de si mesma. ${ }^{22} \mathrm{~A}$ instituição crítica passa a servir de forma para a imagem-vida. Trata-se de uma significaçấo discursiva que adquire estatuto de imagem. A crítica, por se interessar sumamente pela vida, mostra pela forma o quanto ela pode se afastar de si mesma. O ensaio é a imagem que, ao espelhar a imagem-vida, devolve a ela a sua própria intensidade. Quando a crítica pode se afastar das obras de arte, isso se deve um pouco ao aumento de sua capacidade instituinte, mas o méritos são da vida que pôde ser colocada à altura de si mesma.

\footnotetext{
22 "Além disso dois ensaios não podem se contradizer: cada um cria um mundo diferente, e mesmo quando, a título de atingir uma maior universalidade, isso vai além do mundo criado, isso ainda se mantém dentro do seu tom, cor e acento; tal para dizer, isso deixa o mundo apenas em seu sentido inessencial. [...] Por isso, o ensaísta que é realmente capaz de olhar a verdade, vai encontrar no fim de sua jornada o que ele estava buscando: vida. [...] O ensaísta precisa se tornar consciente de seu próprio ser, deve achar a si mesmo e construir algo de próprio para fora de si mesmo." (LUKACS, 2009a, p. 27). Dentro, o ensaio está todo fora de si.
} 
Não seria frívolo perceber a promiscuidade entre a poesia e a crítica, na escritura do ensaio. A necessidade acrescenta ao ensaio algo da prosa poética, uma vez que a verdade tipográfica diz e mostra. Parece sábio notar que as descobertas e demonstraçóes do ensaio se aplicam à poesia, e também o caminho inverso. Se o ensaio gradativamente revela a indistinção entre a imagem e o pensamento na paisagem, no retrato e na abstração - levando a afirmação do caráter tipográfico da verdade, nos momentos em que a poesia evidencia a amplitude da imagem com relaçáo à escrita, ou melhor, a mostraçáo contida no dizer, como no lance de dados de Mallarmé, ou nos gafanhotos de Cummings -, esta deve ser imediatamente incorporada ao corpo conceitual do ensaio e explorada. Lukács o faz, dançando entre a dissertação, a epístola e o diálogo. A crítica defende uma imanência imagética - a unidade dos mundos se dá sobre o branco -, apesar da modalidade na homologia entre o pensamento, a imagem e a escritura, dentro da qual cabe à objetividade do gosto perceber as distinçóes. Lukács salienta que a diferença entre o ensaio e a poesia persiste no fato de que a poesia retira motivos da vida (e da arte), enquanto o ensaio os retira da arte (e da vida).

A fina relação a ser compreendida é aquela entre a alma e a forma. A alma, dentro, está toda fora e a forma, fora, está toda dentro. Imagemvida e significação-vivência nomeiam a experiência. Ou seja, nomeiam tanto a alma quanto a forma. A alma é dependente da forma, para ter vida e vivência, e a forma o é da alma, para ter instituiçóes e aprofundamento. Aquilo que a alma faz para instituir forma é exercer a expressão, a qual consiste numa procura das formas existentes da provocação da necessidade e do gosto, que são as respostas autênticas e espontâneas da necessidade política. Nesse sentido é que a alma busca sempre um gesto que esteja à altura da vida, para que nela possa se reconhecer. Como é a vida que leva à expressão, é certo que o gesto quer estar à altura, ou suspender, da experiência que lhe deu origem. Não se trata de um desvio da obra, mas do elastecimento da vida pelo gosto. Para isso, como destacamos, o crítico assume o mundo dos fatos com o rigor de um esteta, de modo a evidenciar o tênue limite insatisfatório da ciência, mergulhando no objeto em busca da sua composição. O ensaio é a instituição do crítico, pois nele realiza a marca no tempo histórico, cuja gestualidade depende de sentir as representaçóes. Lukács vê nisso o paradoxo do retrato, ao que poderíamos acrescentar que a verdade, porque tipográfica, padece do paradoxo do retrato: ela mostra, na formalidade, os elementos ausentes na vida, para que a forma sobre a vida permita o reconhecimento. $\mathrm{O}$ retrato mostra a verdade ausente na imagem, 
para que a imagem finalmente se reconheça. Eis o aspecto inultrapassável do gosto, para ir à composição da imagem (LUKACS, 2009a, p. 26).

Nessa direção é que se pode sustentar o ensaio como o mais "profundo dos pensamentos antigregos”, o privilégio da relação tipo-vida. Isso é o que faz ver Platáo como ensaísta; o artifício de chegar à vida de modo incidental é uma relação direta do reconhecimento da alma-forma-imagem-vida. Platão seria, na verdade, com sua inovação formal, o diálogo, desviando-se da tragédia e da sofística, o menos grego entre os gregos, senão aquele que inventa uma forma que não aparece num ambiente cosmológico, mas quando dele retirado, surge enquanto estrutura do ensaio. O ensaio é Platão sem platonismo, pois a existência da Grécia, enquanto imagem, só se realiza no aparecimento do diálogo, da Grécia enquanto forma. ${ }^{23}$ De alguma maneira, parece a interpretação de Lukács indicar que a verdade da imagem-vida só é completa quando se faz em tipo. Ou melhor, quando passa a participar do tempo como instituição.

O ensaio é uma forma de arte e, por isso, não é obra de arte; sendo arte, realiza a sua ação também no gosto: existe um tempo da enunciação ensaística, talvez haja um kairós profundamente perturbado pela intempestividade, pelo cedo ou tarde demais; seja como for, o ensaísta procura o tempo certo de dizer, quer ele exista, quer náo, pois enunciar não se justifica por si, mas pela necessidade moral do dizer. O ensaísta vive numa cosmocronia afetável pela imagem-vida, para, num rigor mais do que científico e mais do que artístico, buscar o sentimento de legitimidade para o dizer. $\mathrm{O}$ aparente ensimesmamento do ensaísta decorre da sua adesão intensa à vida. Apenas se institui na busca de altura equivalente ao tempo.

Nas regras do ensaio, estão contidas a vedação à biografia, ao subjetivo e à confissão. Ainda que esses elementos não definam a poesia, nela podem estar contidos. Eles surgem como humor pontual, mas não na composição dos contornos da forma. Se a experiência pode ser parcialmente definida pela relação entre a imagem e a significação, apenas a dualidade entre forma e alma permite o reconhecimento de que se possui um mundo. A natureza humana tem mundo, quando reconhece na dualidade imagem e significação o seu próprio rosto, ao reconhecer a alma na forma. A dinâmica entre imagem e significação - que, pela abstração promovida pela reductio, pode ser vista interrompida, uma vez que a significação é a origem da imagem,

23 “[...] os escritos dos grandes ensaístas, aos quais pertencem a categoria: os diálogos de Platão [...], os ensaios de Montaigne [...].” (LUKACS, 2009a, p. 18). 
e a imagem o é da significação - pode ser compreendida como um plano de pictorialidade, porque é presença de plena disponibilidade carecedora de instituição, atendente à gradação cromática, embora não seja o caso de dar exemplo de uma relação ontológica, porque certo que nada mostra melhor essa dimensão do que os quadrados de Malevich. No branco, existe imagem e disponibilidade à significação e, no quadrado, pode ser no negro, existe forma e índice para o reconhecimento. Também entre a alma e a forma, a distinção nasce da reductio, pois a forma é um efeito da alma. Por outro lado, a alma é um efeito da imagem-vida-forma. Não é que haja experiência sem forma, mas existe algo na vida-imagem, a expressão, que ultrapassa a forma.

A necessidade enunciativa do ensaio crítico nasce da moralidade e da política; cabe dizer que a ocultação da crueldade na imagem leva à reação do dizer expressivo. Existe uma naturalidade na progressão do tempo da imagem e suas relaçôes de significado. Esta pode ser percebida na constatação de que o tempo da vida tem certo ritmo (LUKACS, 2009b, p. 42). Acelerá-lo ou atrasá-lo é um efeito. O ceticismo identificou bem essa rítmica, e a denominou hábito. Se a perspectiva do hábito é o tempo, o mesmo não pode ser dito para a alma e a forma. Algo da agigantada expressividade da alma decorre da extração desse princípio luminescente do tempo. A alma retira sua existência do tempo. Todavia, a rítmica da forma não é horizontal, tal como a da vida. A rítmica da forma obriga a imagem a um abismo vertical. A alma, ao se instituir formalmente sobre o tempo, leva a imagem a se tornar objeto capaz de uma rítmica própria. A forma confere uma vida própria à sua instituição, conferelhe um tempo próprio. Essa imagem própria do tempo não deixa de estar inscrita no corpo rítmico, sendo-lhe submissa. Mas o acompanhamento da imagem de vida própria segue a horizontalidade, verticalizando-se, podendo se atrasar com relação à vida, atrapalhá-la, congelar-se às raias do insuportável ou, mesmo, antecedê-la um pouco. Basicamente, são três modelos da imagem de vida própria: neles, o ponto de saída das duas retas é o de instituição - a primeira reta é a imagem-vida (rítmica) e a segunda, a imagem de vida própria.

( $\mathrm{I})$

Quão mais obtusa a imagem de vida própria, mais resistente é o seu tempo com relação à vida. Pode-se dizer que são imagens nas quais o gosto tem mais dificuldade para se aprofundar, visto que são mais abissais, mas também são as mais belas e as mais virtuosas. Deve-se perceber que o 
ponto de instituição se inscreve por crueldade da forma contra a imagemvida, ainda que seja para apresentar revivescência imprevista. Tal crueldade, contudo, distingue-se daquela geradora da necessidade enunciativa do crítico no ensaio, pois tal crueldade, contra a qual o ceticismo desde Montaigne escolheu se voltar contra, é aquela presente no apagamento do rastro da alma na forma. Há, portanto, a crueldade de se instituir sobre o tempo a forma da alma e a de se apagar o rosto humano nas imagens; esta segunda realiza-se pela transcendência, pela moral abstrata e pela burocracia. A crítica precisa ser capaz de ver a segunda forma de crueldade, para ser capaz de instituir a forma da alma sobre o tempo. Tal sensibilidade ao apagamento do rosto humano na imagem se chama crudelis meditatio.

(II)

É característico da instituição conservadora, mas também da imagem de vida própria, atinente ao aprofundamento do gosto. Pode-se dizer que esta é a imagem mais cruel em sua instituição e mais ligada à beleza e a virtude. Quão mais o gosto nela se aprofunda, mais relevantes são as distinções que é capaz de fazer. O apagamento do rosto humano, nesse caso, é quase sempre identificado com o fetichismo. Como o vício nasce da mesma matéria da virtude, o fetichismo surge no encantamento com a distinção pela distinção. Ainda que náo exista a interrupçấo da rítmica do tempo da imagem-vida, estar nos dois pontos da imagem gera a sensação de tempo que passa mais devagar. Não é de todo incorreto associar esse segundo modelo com a ideia de duração, porque é justamente o tempo do gosto a ser mais relevante para o objeto do que a própria rítmica da vida. Além disso, é nesse modelo que se pode compreender a transfiguração da instituição em obra.

Responde por uma imagem de vida própria que artificialmente se adianta ao tempo da vida. Ela se faz por uma autêntica urgência de mudança de rumo, no caso da revolução, pelo esforço de falseabilidade, no caso da tentativa de alteraçáo dos esteios da verdade, ou ainda de suspensão das imagens pela demonstração de que o adiantamento é a evidência da essência do tempo. Quão mais agudo é o ângulo, mais destrutiva é a instituição, uma 
vez que sua rítmica perecerá muito mais rápido do que a vida. Não só filosofias da história são abrigadas nesse modelo, mas filosofias da natureza. Se o ângulo se torna obtuso, troca-se uma filosofia da transformação por uma da salvação.

\section{VI}

Diante do encobrimento da composiçáo da imagem, efetivado pela crueldade, o que leva ao apagamento da alma humana nas coisas, a falta de compromisso do poeta com o crítico, no mais das vezes, ajuda à crítica. Se a crítica realiza uma crueldade instituinte, para promover o gosto na imagem, de modo a se contrapor à crueldade de apagamento do rosto, a poesia é uma atividade sem crueldade e sem crudelis. À poesia náo cabe o mergulho na composição da imagem consolidada, mas o trabalho no colorido da vida. Se a crítica explora a variabilidade rítmica, até mesmo pela inovação formal, a poesia cria, entre as cores da imagem-vida, dissonâncias, e para isso não pode hesitar como o crítico. Lukács vê, no âmbito moral, a poesia como preparação crítica e a crítica como preparação poética. ${ }^{24} \mathrm{~A}$ poesia fala sobre si, mas não se confessa. Se repete o mesmo percurso, a crítica passa a falaciosamente dar ares de confissão à objetividade. A poesia também vive o dentro, fora; ao se aprofundar na dissonância, não se ocupa com instituir objetos, mas em ser um objeto a dissonar ambivalentemente. Por essa razão, Lukács assevera que o poeta enuncia a verdade sobre a imagem, e o crítico, a verdade sobre a imagem pela poesia (LUKACS, 2009b, p. 37). Se a poesia está no plano da dissonância da vida, a crítica se estabelece na resolução da imagem pelo reconhecimento da alma na forma (LUKACS, 2009b, p. 38). Há mais realidade para o poeta e mais irrealidade para o crítico. O poeta é o homem do mundo e o crítico, dos mundos. ${ }^{25}$

"As asas que Deus lhe deu/Ruflaram de par em par [...]" dito pelo poeta não significa adesão à transcendência, pode, inclusive, significar outra

\footnotetext{
24 "Talvez a vida exista como uma realidade apenas para o homem cujos sentimentos possuem tal dissonância [hesitação entre forma e cor]. Talvez 'vida' seja justamente a palavra que significa, para o platonista [o crítico], a possibilidade de ser poeta, e para o poeta a possibilidade de ser platonista [crítico] em sua alma." (LUKACS, 2009b, p. 40). O poeta precisa do crítico para ter mundos e viver a transversalidade do seu próprio, e o crítico precisa do poeta para ter vida.

${ }^{25}$ Ibid., p. 37. "O poeta sempre fala sobre si mesmo, não importando o que significa; o platonista não se atreve a pensar alto sobre si mesmo, ele apenas experiencia a sua própria vida pela obras dos outros, e entendendo os outros, ele se torna mais próximo de si mesmo."(LUKACS, 2009b, p. 37. "Todo platonista fala suas mais importantes palavras sobre o poeta." (LUKACS, 2009b, p. 42).
} 
coisa bem diferente, tal como um vínculo imanente ao Deus na linguagem. Todavia, para o crítico, tal dissonância, de falar de Deus para explicar o quáo faltantes são as asas, esconde uma verdade a ser mostrada e, para isso, o crítico, por um momento, pode pensar como quem crê, depois como quem não crê e ainda se interessar pela crença, crendo. O crítico percorrerá uma cadeia de possibilidades da vida poética, e nos mostrará, no tipo, pela instituição de uma forma, o modo pelo qual podemos reconhecer na vida, em suas posiçóes mais variegadas. Ou, se for o caso, mostrar os momentos em que, por moralidade, não podemos nos reconhecer. A vontade de sistema do ensaio é factual, contudo, não serve ao sistema; um ensaísta pode mostrar ter muitos sistemas e não ter nenhum. Porque todos os sistemas se submetem à teoria da imagem intrínseca a necessidade moral do ensaio, desencobrir a crueldade. Por esse motivo é que a forma concerne a fazer uma expressão maior do que as circunstâncias biográficas, seja a forma poética, seja a ensaística. O poeta é maior do que si ao falar. Nos demais momentos, deve ser bem pequeno. $\mathrm{O}$ tamanho exato do poeta é indeterminável. Isto é, muito menor do que pensa e muito maior do que se imagina. Não se deve confundir as instâncias. Não porque imagem e forma seja distintas, mas porque precisam do desnível para encontrar expressão. A imagem-vida prepara o salto da forma, por ser menor e monumental. Sem a constatação da menoridade estratégica da imagem diante da forma não se pode compreender o modo pelo qual a vida se agiganta diante da forma instituída. Do contrário, a vida se espiralaria fenecente e, com ela, a forma levaria. Ao se desejar a vida menor do que a forma, o único resultado possível é o constrangimento enunciativo, ao percebê-la monumental (LUKACS, 2009c, p. 48). Para evitá-lo, poesia e ensaio partem de um mesmo estado de economia performativa. O gesto não é a vida toda, ele é preparado pelo gosto na vida, e se manifesta para a ultrapassar, ao que é surpreendido pelo estabelecimento da vida e uma nova necessidade de preparo. $\mathrm{O}$ aplacamento da frugalidade do gesto é a instituição da forma no tempo, fazendo notícia da dissonância, no caso da poesia, e da interpretação, no caso do ensaio. Um gesto ultrapassa o jogo de linguagem para repô-lo mais abrangente, elastecendo o mundo (LUKACS, 2009c, p. 45-47).

"O gesto: quebra a ambiguidade do inexplicável." (LUKACS, 2009c, p. 46). Não obstante, nele a ambivalência não é negada ou resolvida. Se a crueldade apaga o rosto humano, e o vislumbramento da ambivalência da crueldade em nós, o faz pela vocação de negar a ambivalência. A ambiguidade é o falso problema que afasta a ambivalência, o ensaio quebra a ambiguidade para recolar a ambivalência. O ambíguo encobre a crueldade, ao passo que 
a ambivalência a expóe. A poesia vive a ambivalência dissonantemente em primeira pessoa, enquanto o ensaio busca desencobrir a ambivalência, ao perceber o índice ambíguo. Não a nega, e não a relativiza, sobre ela institui o critério da moralidade. É relevante que nem toda vida seja ensaio ou poesia, mas que aconteçam, quando necessário.

A sensibilidade ao ambíguo é o principal legado do pessimismo à tradição do ensaio; talvez se possa asseverar que o pessimismo lhe tenha se tornado próprio, ainda que nem todo ensaio o mobilize. $\mathrm{O}$ pessimismo surge na tradição do ensaio para realizar a crítica ao progresso; uma vez que a crítica abraça o mundo dos objetos, e não se interrompe antes, existe certa tendência do ensaio à defesa do construtivismo social, e mal compreendido, pode ser associado ao desenvolvimento, no seu sentido amplo, mas nada mais enganoso. Ensaístas como Kierkegaard e Schopenhauer, ou até mesmo Cioran, para criticar o progresso moral e político, mostram que o aparente controle sobre a ambiguidade não significa percepção da ambivalência da crueldade. Eles alertam que a crueldade, além de instituir um objeto e elastecer o mundo, cria, na mesma proporção, dimensôes regressivas. Se a instituição, pela crueldade, inscreve-se no tempo de modo ambivalente, e se ela, no tempo, é capaz de se fazer durar, tal como percorre o gosto pela distinção, também seria capaz de produzir abismos destrutivos no tempo. Por assim dizer, a instituição, no caso, abriria, sob si, camadas de abissalidade. Por exemplo, segundo a perspectiva do pessimismo, a instituição de uma vontade de comunicação universal não teria apenas a crueldade inexorável a toda instituição, moral ou imoral, cuja ambiguidade serve de índice para o exercício do desencobrimento por moralidade, mas também a ambivalente constituição de uma abissalidade da falta de compreensão.

O pessimismo dá estrutura ao que Lukács denomina fundação da forma contra a vida. Ainda que a contraposição entre a forma e a vida seja sempre frustrada, pois o seu derradeiro ato, o suicídio, existe apenas enquanto ideia, a sua prática, tirando a problemática ensaísta de vê-lo como meio gesto ou como modulação do suicídio de uma ideia, significa apenas a morte de um homem. O pessimismo é um ensaísmo que rouba nas regras do ensaio, ele estetiza a existência. Faz com que a vida mesma seja a obra de arte e distancia o corpo da moralidade comum, fazendo-o totem de um enunciado contrário à vida. No pessimismo, o corpo se torna a própria vida, e a vida se torna um arremedo insuficiente daquilo que o corpo é. $\mathrm{Na}$ 
estetização da existência, tudo quanto há é limitador da forma do corpo, cuja expressão passa a se dar na denúncia àquilo que prende o corpo. Assim, a forma não se dá por gesto escritural de uma verdade tipográfica, mas pela exibição da agonia. Em alguma medida, e não de modo fatal, e não que náo se possa aproveitar os pontos fortes de outra maneira, o pessimismo é o cristianismo no ensaio. Naquilo que tem de mais fundamental, uma obsessão com o corpo.

Se é necessário, para o corpo crítico, que a solução venha pela forma, o ensaio não é corpo, mas a sua precipitação instituinte, pictórica, enquanto vontade de rosto nas coisas (LUKACS, 2009b, p. 37). O pessimismo evita a dramaturgia, tal como a crítica, porém, ele o faz tornando o corpo agônico no único personagem, isso é o bastante evidente, reagindo às forças que diminuem o que pode um corpo; mas o ensaio o faz tornando o objeto em um manifesto contra essas muitas forças; nesse sentido é que a moralidade da perscrutação da crueldade se torna exercício de filosofia pública. As muitas forças divergentes são matéria de instituição para o ensaísta, por isso, a sua vocaçáo construtivista, oposta à tendência destrutiva, por abandono, do pessimismo. Se o ensaio é um ceticismo com relação à substância da verdade, fazendo-a pictórica, porque tipográfica, o pessimismo é um ceticismo acerca de valores, cuja ação é o fetichismo do corpo próprio.

Todavia, a verdade seja dita, tanto o pessimismo quanto o construtivismo ensaístico reagem agressivamente à formalização dramatúrgica da vida pública. Esse processo deveria ser descrito pela relaçáo de continuidade de certos personagens sociais, em função da estabilidade constituinte. ${ }^{26}$ Uma vez que economia e sociedade mantêm certos padróes de constituição das instituições, as instituições novas não são capazes de fazer oscilar os personagens sociais, pintando-os sempre nos mesmos dramas. Os pessimistas percebem a oscilaçáo do dramatúrgico, em virtude do fato de que o grande personagem instituinte é o corpo, e o corpo nunca é o mesmo personagem. Os construtivistas argumentam que a instituição do

\footnotetext{
26 "Um personagem dramático é impensável sem a permanência de características; na perspectiva do drama, simplesmente não vemos sem essas características; as momentâneas são esquecidas em um instante. A repetição de um traço é não mais do que um equivalente técnico de um destino profundo na constância das características, do personagem." (LUKACS, 2009b, p. 41). Lukács salienta que o crítico não crê em repetiçóes que não as afetivas, levando à condição da inventividade de personagens, em detrimento da estabilizaçấo dos velhos, e seus velhos casacos. Um velho personagem é um velho casaco.
} 
personagem é vinculadora do próprio ambiente constituinte, de sorte que as repetiçóes estruturais nunca são dramatúrgicas, e o teatro público consiste numa vulgarização da imagem, iniciado pela popularização do romance e arraigado nas formas contemporâneas de entretenimento.

KIRALY, César. The essay in Lukács: the later style and the youthful form. Tans/form/açâo, Marília, v. 40, n. 1, p. 51-86, Jan./Mar., 2017.

ABSTRACT In this article I look to establish affinities between the skeptical tradition and the dialectic, by means of the concept of criticism.

KeYwORDs: Lukács. Skepticism. Dialectic.

\section{REFERÊNCIAS}

ADORNO, T. W. Jargon de L'authenticité. Paris: Payot, 1989.

$15-45$.

O ensaio como forma. In: Notas de literatura. Sáo Paulo: Editora 34, 2003. p.

BAYLE, P. Dictionaire historique et critique. Amsterdam: Fac-Similé, 1740.

CASSIRER, E. A filosofia do iluminismo. Campinas: Editora da UNICAMP, 1994.

KOSELLECK, R. Crítica e crise. Rio de Janeiro: Editora da UERJ, 1999.

LUKÁCS, G. A teoria do romance. São Paulo: Ed. 34, 2000.

Destruction of reason. Pontypool: Merlin Press, 2005.

LUKÁCS, G. On the nature and form of the essay. Translated by Anna Bostock and Judith Butler. In: SANDERS, J. T.; TEREZAKIS, K. (Ed.). Soul and form. New York: Columbia University Press, 2009a. p. 1-18.

. Platonism, Poetry and Form. Translated by Anna Bostock and Judith Butler. In:

SANDERS, J. T.; TEREZAKIS, K. (Ed.). Soul and form. New York: Columbia University Press, 2009b. p. 19-27.

. The Bourgeois Way of Life and Art for Art's Sake. Translated by Anna Bostock and Judith Butler. In: SANDERS, J. T.; TEREZAKIS, K. (Ed.). Soul and form. New York: Columbia University Press, 2009c. p. 55-78.

. The Foundering of form against life. Translated by Anna Bostock and Judith Butler. In: SANDERS, J. T.; TEREZAKIS, K. (Ed.). Soul and form. New York: Columbia University Press, 2009d. p. 28-41. 
KIRALY, C

STRAND, M. The monument. In: New selected poems. New York: Alfred A. Knopf, 2010.

Recebido em 10/06/2016

Aceito em 12/11/2016 